NATURE

No. 4065 SATURDAY, SEPTEMBER 27, 1947 Vol. 160

\section{FREEDOM OF THE PRESS}

$T$

WO recent publications, namely, a book by $\mathrm{Mr}$.

Kingsley Martin published in Great Britain*, and a General Report by the Commission on Freedom of the Press prepared in the United Statest, are devoted to consideration of the freedom of the Press, using that term in its wide sense. Both state clearly the issues involved and in such a way that there can be no mistaking the implications in the scientific field. The American report, for example, emphasizes the way in which freedom of expression tends to lift the level of social conflict from the plane of violence to that of discussion : it is part, in fact, of the method of democracy as of science, and the effective agencies for safeguarding it are the community and the Government ; of these two, Government, through its elementary responsibility for maintaining order and personal security, comes first. We must also face frankly the fact that freedom of the Press is dangerous and open to abuse, just because it makes high demands on reasonableness in the public mind; equally we must recognize that the very power of Government to secure freedom of expression involves the possibility of infringement.

The American Commission stresses, therefore, that if freedom of the Press is to be real, Government must set limits upon its own capacity to interfere with the Press or to manipulate the data on which public judgment is formed. It is the mark of a free society that in it the Government does expressly limit its scope of action in regard to certain humun liberties which are not only important interests but also moral rights, and of these freedom of expression is one. Such moral rights are not, however, uncon. ditional, and the report does well to stress the element of responsibility which is inseparably built into any such moral right. That element does not, it is true, exclude the possibility of error. Liberty to experiment and, by implication, trial and error, involve the possibility of wrong opinions or false conclusions. What is excluded is the right to be deliberately or irresponsibly in error.

Again, abuse of a right does not ipso facto lead to forfeit of the protection it affords, although there are limits to the legal toleration of abuse of freedom of expression. Such limits are based on the common principle that utterance or publication must not invade in a demonstrable manner recognized private rights or vital social interests. Moreover, a further question of public responsibility arises to-day in view of the extent to which public interest affects the functions of the Press, and the American Commission urges that the Press must now assume as its own objectives those of the community for the Press. It recognizes an antithesis between the current conception of the freedom of the Press and its accountability, and points out that the Press must recognize that its faults and errors have ceased to be private vagaries and have become public dangers. The Press

* The Press the Public Wants. By Kingsley Martin. Pp. 143. (London: Hogarth Press, 1947.) 78. 6d. net.

+ A Free and Responsible Press. A General Report on Mass Communication: Newspapers, Radio, Motion Pictures, Magazines and Books. By the Commission on Freedom of the Press. Pp. xil +139 (Chicago: University of Chicago Press; London: Cambridge University Press, 1947.) 2 dollars. 
must accept the public standard and endeavour to achieve it.

The conception of freedom of the Press brought out in this report is that of freedom from compulsions from any sources, though not from pressures. It implies also a Press free for the expression of opinion in all its phases, and free also to achieve the goals of service in which its own ideals and the requirements of the community combine and which existing techniques make possible. It means also a Press free to all who have something worth saying to the public.

The specific recommendations which the Commission makes to further this ideal fall into three groups. First, a Government may improve the conditions under which Press activities function, so that the public interest is better served, by improving distribution, removing hindrances to the free flow of ideas, reducing confusion and promoting the reality of public debate. It is because of the grave handicap which they impose on public debate and the effective distribution of news and comment that the latest cuts in newsprint are so deplorable, above all at a time when on the international plane the United Nations Educational, Scientific and Cultural Organisation is attempting to improve conditions in just the way suggested. Furthermore, it is suggested that Government should enter the field of Press comment and news supply, not as displacing private enterprise, but as a supplementary service, which may even present standards for emulation.

In making this general recommendation, the Commission has particularly in mind the introduction of new techniques, and reflects also the American dislike of trusts, though it is suggested that to maintain competition the anti-trust laws should only be sparingly invoked. It recommends that the constitutional guarantees of the freedom of the Press be recognized as including the radio and the cinema film.

The second group of recommendations relates to action by the Press itself. These include the acceptance of its responsibility as a common carrier of information and discussion, and the assumption of the responsibility of financing new experimental activities in the different fields of mass communication. Vigorous mutual self-criticism by members of the Press and the use of every possible means of increasing the competence, independence and effectiveness of staff are also recommended, and finally, that the radio industry should control its programmes and treat advertising as it is treated by the best newspapers.

The third group of three recommendations relates to action calling for public initiative and pre-supposing recognition of the vital importance of the Press. First of these is the use of non-profit institutions to help to supply the variety, quantity and quality of the Press required. Next comes the creation of academic centres of advanced study, research and publication in the field of communications, as well as the co-operation of existing schools of journalism with the universities to give their students the broadest and most liberal training. Finally, the Commission recommends the establishment of a new and inde- pendent agency to appraise and report annually on the performance of the Press. The activities of this agency are also outlined; but although they include the encouragement of the establishment of centres of advanced study, research, and criticism in the field of communications at universities, it is difficult to believe that much support would be forthcoming for the establishment of such an agency in Great Britain. The need for centres of investigation, graduate study and critical publication may be admitted, though it might well be a field in which the initiative, if not the organisation, should come from the United Nations Educational, Scientific and Cultural Organisation. Such studies and research might well be planned internationally even if carried out in national institutions.

It is to the cumulative effect of these recommendations rather than to any one, or any group, of them that the Commission looks to bring the performance of the Press closer to meeting the ideal demanded by society for the communication of news and ideas : a truthful, comprehensive and intelligent account of the day's events in a context which gives them. meaning ; a forum for the exchange of comment and criticism; the projection of a representative picture of the constituent groups in the society ; the presentation and clarification of the goals and values of the society; and full access to the day's intelligence. That ideal is also formulated very clearly in $\mathrm{Mr}$. Kingsley Martin's book, as indeed it was by Mr. Francis Williams in his "Parliament, Press and People" last year; though possibly Mr. Kingsley Martin sets out more clearly the limitations imposed by the state of the public mind. He recognizes that we cannot ignore the fact that comparatively few people have a passion for truth as a principle, or care about public events continuously when these do not obviously affect their own lives, and even the scientific worker with his disinterested desire for knowledge in his particular field may not apply the discipline of the laboratory to his political thinking.

Mr. Kingsley Martin covers a more limited field than did Mr. Williams, and his historical and critical chapters are excellent and apposite. Iike the American Commission, he defines clearly the central problem of combining responsibility with freedom; but when he comes in his concluding chapters to "The Public Concern" and "Public Opinion in One World", he is diffident and less sure of himself. Three lines of advance, indeed, he points out, two of which are noted by the American Commission : the media of mass communications must become increasingly public concerns; our educational system must be better devised to create a conscious citizenship ; and we must be given more chance to play an active part in the community life around us which we understand.

Mr. Kingsley Martin reviews succinctly the various suggestions that have been made for increasing the responsibility of the Press without endangering its freedom of presentation of news and comment, but without lending emphatic support to any. The main emphasis is laid on safeguarding the freedom of the journalist by raising his professional status and on guaranteeing the independence of the editor. $\mathrm{He}$ 
insists, too, that hope of a public which can judge political issues and steadily demand-and, therefore in the long run obtain-a better news service and a more informed type of comment, depends on the educational system, which must deliberately aim at the substitution of knowledge for prejudice in public affairs and the cultivation of the type of critical and informed mind which can apply itself to life as a whole and not only to specialized interests.

While Mr. Kingsley Martin, like the American Commission, emphasizes the professional contribution of the journalist, what he has to say about the importance of the local community and the business or professional association should be noted. $\mathrm{He}$ seems to be expressing much the same idea that Sir Alexander Carr-Saunders and Mr. P. A. Wilson voiced in their study of the professions, of the professional men finding in their vocational associations the permanent anchorage and shelter from which they could set out to shape organisations into instruments for the fulfilment of their purposes. It has its message for scientific men in particular as they face in the narrower field of scientific communications whatever dangers may be involved in the infection of Governments with the idea of military secrecy.

There is, as Mr. Kingsley Martin points out, an ever widening demand which increased secondary education has already evoked for news and comment which is independent of the control of the great proprietors owning most of the daily newspapers. The growth of a critical public is a hopeful sign, though the importance of this factor should not be exaggerated.

Both Mr. Kingsley Martin's book and the American report should help to clarify the confused thinking about public responsibility on the part of the Press which found reflexion in the establishment of a Royal Commission, and equally on the Government's disregard of public responsibility both in the ban on periodicals last winter and in the recent cuts in newsprint. The Government may not desire to suppress free comment; nevertheless, it can be accused of indifference to the importance of free comment and discussion. Both the publications under discussion should make an important contribution to the creation of that informed and alert public opinion on which in the last resort scientific workers themselves must rely for preservation of freedom of communication and public discussion.

\section{WHITEHEAD'S COLLECTED ESSAYS}

\section{Essays in Science and Philosophy}

By Alfred North Whitehead. Pp. vii+348. (New York: Philosophical Library, Inc., 1947.) 4.75 dollars.

$\mathrm{I}^{\mathrm{s}}$ T was a happy idea to collect in one volume the occasional writings which Whitehead has produced from time to time in magazines and such-like places. How far the present assembly is complete is not stated; and if it is incomplete, there is no indication as to whether the choice of what should be included was made by Whitehead himself or by an editor.
The first part of the book is labelled "Personal", and consists for the most part of descriptions, intended for the information of American readers, of the author's boyhood environment in north-east Kent. They make pleasant armchair reading, enlivened by stories such as that of a neighbouring High-Church clergyman, who "introduced an altar cloth with the sacred monogram which can be read as the Latin capital letters I.H.S. This aroused some Protestant feeling, which was allayed only by the happy conjecture that the letters stood for Jenkins, Harvey and Snowden-the surnames of the vicar and his two curates." There is not as much as one would like about Whitehead's intellectual development: he. tells us that his first great work, the "Universal Algebra", was inspired by Grossmann's "Ausdehnungslehre", Hamilton's "Quaternions" and Boole's "Symbolic Logic" (but this has always been evident); and we learn that he could never read Hegel. The ending of his long and marvellously fruitful partnership with Bertrand Russell is briefly referred to in the words: "Our fundamental points of view-philosophic and sociological-diverged, and so with different interests our collaboration came to a natural end".

The more serious part of the book begins with an essay on "Immortality", written in 1941 and already familiar to many readers from its inclusion in the Whitehead volume of the "Library of Living Philosophers". The main thesis in this paper is that we naturally simplify the complexity of the universe by considering it in the guise of two abstractions, namely, the world of activity and the world of value. The prime characteristic of the one world is change, and of the other world is immortality. Each of these worlds is futile except in its function of embodying the other-value refers to fact, and fact refers to value. Either world can be described only in terms of factors which are common to both of them : such factors have a dual aspect, and each world emphasizes one of the two aspects : the factors are no other than the Platonic "Ideas". A key example for understanding the fusion of the world of activity and the world of value is the problem of "personal identity" in a changing world of occasions : here the immortality which belongs to value has entered into the changefulness which is the essential character of activity.

The world of value exhibits the essential oneness of the universe. Thus while it brings into view the immortal side of the many persons, it also involves the integration of personality. This is identified by Whitehead with the concept of God, who is the intangible fact at the base of finite existence, a unification founded on ideals of perfection, moral and æsthetic ; to ascribe arbitrary power to Him is a profanation. Clearly this is not the God of the Christian theological tradition, nor is it the diffused God of the Hindu-Buddhistic tradition; the concept lies somewhere between the two.

An article on "Analysis of Meaning", reprinted from the Philosophical Review of 1937, contains a remarkable suggestion with regard to the prospects of the author's favourite study, symbolic logic. When in the distant future the subject has expanded, so as to examine patterns depending on connexions other than those of space, number and quantity, then, Whitehead suggests, symbolic logic (that is to say, the symbolic examination of patterns with the use of real variables). will become the foundation of æsthetics; and from that stage he anticipates that it will proceed to conquer ethios and theology. 